\title{
PENINGKATAN HASIL BELAJAR IPS MELALUI MODEL PEMBELAJARAN KOOPERATIF PICTURE AND PICTURE SISWA KELAS V A SD NEGERI 200402 SABUNGAN PADANGSIDIMPUAN 2017- 2018
}

\author{
NURHALIMA TANJUNG, S.Pd \\ NIP: 196308261983042001. \\ Email:nh2394649@gmail.com
}

\begin{abstract}
abstrak
Tujuan penelitian ini adalah untuk mengetahui apakah hasil belajar IPS dapat diupayakanmelaui penerapan model Pembelajaran koperatif picture and picture Siswa kelas V A SD Negeri 200402 Sabungan Padangsidimpuan Tahun Ajaran 2017/2018.

Jenis penelitian ini adalah Penelitian Tindakan Kelas (PTK), model PTK yang digunakan spiral dari Kurt Levin yang dilaksanakan 2 siklus terdiri dari perencanaan tindakan, implementasi tindakan dan observasi serta refleksi. Variable penelitian menggunakan 2 variabel, yaitu model Picture and Picture dan Hasil belajar IPS. Tehnik pengumpulan data menggunakan tehnik non tes (skala sikap). Adapun tehnik analisi yang digunakan adalah statistk deskriptip komparatif melalui table, grafik, diagram lingkaran dan skor maksimal, skor minimal, perhitungan persentase.

Hasil penelitian menunjukkan bahwa tindakan melaui model pembelajaran kooperatif picture and picture meningkatkan hasil belajar siswa kelas V A SD Negeri 200402 Sabungan Padangsidimpuan Semester I Tahun Ajaran 2017/2018. Hal ini Nampak pada hasil perbandingan skor hasil belajar IPS antar siklus yakni skor rata-rata hasil belajar IPS pada siklus I sebesar 85,27, pada siklus II meningkat menjadi 90,10. Skor maksimal pada siklus I sebesar 94 pada siklus II meningkat menjadi 97 sedangkan skor minimal pada siklus I sebesar 64 dan pada siklus II menjadi 81. Adapun pada siklus I yang siswa yang menduduki hasil belajar tinggi yaitu 18 siswa (75\%) pada siklus II meningkat menjadi 24 siswa (100\%). Kenaikan skor hasil belajar IPS siswa yang menduduki hasil belajar tinggi dari siklus I ke Siklus II sebesar $25 \%$.

Berdasarkan hasil penelitian, maka disarankan untuk diterapkan dalam pembelajaran IPS SD untuk KD 1.3. siswa dapat menghargai keragaman suku bangsa dan budaya di Indonesia guru mendesain pembelajaran dengan menggunakan model pembelajaran Picture and picture untuk memperbaiki pembelajaran dan meningkatkan hasil belajar.
\end{abstract}

Kata Kunci: hasil belaiar. kooperatif picture and picture.

\section{PENDAHULUAN}

Pelaksanaan pembelajaran IPS seperti menghargai keragaman suku bangsa dan yang diutarakan di atas, merupakan gambaran budaya di Indonesia, dengan Kriteria Ketuntasan yang terjadi di SD Negeri 200402 Sabungan Minimal (KKM) $\geq 75$ sebanyak 24 siswa ada 14 Padangsidimpuan. Berdasarkan yang dilakukan siswa $(58,3 \%)$ tidak memenuhi KKM yang pada refleksi awal pembelajaran IPS dinyatakan ditentukan oleh guru dan hanya 10 siswa $(41,7 \%)$ bahwa guru kurang variatif dalam menggunakan dapat memenuhi KKM dengan skor maksimal 80 metode pembelajaran yaitu pada saat dan skor minimal 50. Berdasarkan akar memberikan materi hanya berupa ceramah dan permasalahan yang telah dipaparkan di atas untuk lebih menekankan pada hafalan, keaktifan siswa mengatasi masalah tersebut diperlukan perubahan untuk bertanya dan menjawab pertanyaan dalam model pembelajaran guru yang inovatif dan kegiatan KBM masih belum optimal, sehingga menyenangkan . salah salah satu nya adalah siswa kurang berminat dan antusias juga dengan model pembelajaran pictures and merupakan penyebab kurang optimalnya pictures. Model pembelajaran pictures and pembelajaran, serta guru kurang maksimal dalam pictures diharapakan dapat meningkatkan hasil memanfaatkan media dan penggunaan alat peraga belajar IPS. Menurut Hamdani (2011:89) model selama proses pembelajaran.Menurut hasil picture and picture adalah model belajar yang evaluasi dengan KD adalah 1.4 Siswa dapat menggunakan gambar dipasangkan atau 
diurutkan menjadi urutan logis. Pembelajaran ini (acting) dan pengamatan (observing), dan memiliki ciri Aktif, Inovatif, Kreatif, dan Refleksi (reflecting).

Menyenangkan. Model Pembelajaran ini mengandalkan gambar sebagai media dalam proses pembelajaran, Kompetensi dasar ( KD) 1.3 adalah Siswa dapat menghargai keragaman suku bangsa dan budaya di Indonesia. penggunaan Model pembelajaran pictures and pictures sudah sangat tepat. Mengingat bahwa Kompetensi Dasarnya adalah Siswa dapat sistem pengajaran yang telah dilaksanakan.

menghargai keragaman suku bangsa dan budaya di Indonesia, maka pemilihan gambargambar macam-macam suku di Indonesia tersebut diharapkan dapat membantu dalam proses kegiatan belajar yang sedang berlangsung. Gambar-gambar ini sangat membantu untuk mewujudkan realitas yang tidak saja dapat dilihat, tetapi juga dapat direkam dalam otak masing-masing anak.

Berdasarkan uraian di atas, maka dilakukan penelitian tindakan kelas yang berjudul "Peningkatan Hasil Belajar IPS melalui Model Pembelajaran Kooperatif Picture and Picture Siswa Kelas V A SD Negeri 200402 Sabungan Padangsidimpuan 2017-2018”.

\section{METODE PENELITIAN}

Jenis penelitian dalam penelitian ini adalah penelitian tindakan kelas (PTK) kolaborasi yang menggunakan desain penelitian kemmis dan Mc. Taggart.

Jenis penelitian ini adalah penelitian tindakan kelas ( PTK ) partisipan. " dimana orang melaksanakan penilian harus terlibat langsung dalam proses penelitian sejak awal sampai dengan hasil penelitian berupa laporan. Dengan demikian, sejak perencanaan penelitian observer senantiasa terlibat, selanjutnya observer memantau, mencatat dan mengumpulkan data, lalu menganalisis data serta terakhir dengan melaporkan hasil penelitian tersebut. PTK disini observer dituntut keterlibatannya secara langsung dan terus menerus sejak awal sampai akhir penelitian " (Iskandar, 2011:27).

Desain PTK menurut Kemmis dan Taggart yaitu berbentuk spiral dari siklus yang satu ke siklus berikutnya. Konsep pokok penlitian tindakan menurut kemmis dan Mc Taggart terdapat tiga tahap rencana tindakan, meliputi: perencanaan (Planning), tindakan

\section{HASIL DAN PEMBAHASAN PENELITIAN}

Pertemuan I dan II pada Siklus I guru menerapkan pendekatan $\mathrm{P}$ seperti yang sudah dijelaskan . guru memberikan tes formatif pada pertemuan II setelah kegiatan pembelajaran pada siklus I dari pertemuan I dan II dilaksanakan maka selanjutnya diadakan refleksi dalam bentuk diskusi. Refleksi dan analisis hasil tes (unjuk kerja) pada siklus I terdapat 18 siswa atau $75 \%$ yang tuntas dan yang belum tuntas 6 siswa atau $25 \%$. Sehingga perlu diadakan perbaikan pembelajaran, berikut merupakan hasil belajar IPS pada siklus I

Table 4.3 Distribusi Hasil Belajar IPS pada Siklus I

\begin{tabular}{|c|c|c|c|}
\hline No & Skor & Frekuensi & $(\%)$ \\
\hline 1 & 62 & 6 & 25.0 \\
\hline 2 & 76 & 3 & 12.5 \\
\hline 3 & 78 & 2 & 8.3 \\
\hline 4 & 86 & 1 & 4.2 \\
\hline 5 & 88 & 2 & 8.3 \\
\hline 6 & 90 & 1 & 4.2 \\
\hline 7 & 91 & 2 & 8.3 \\
\hline 8 & 92 & 2 & 8.3 \\
\hline 9 & 93 & 2 & 8.3 \\
\hline 10 & 94 & 3 & 12.5 \\
\hline
\end{tabular}

Pertemuan I dan II pada Siklus II guru menerapkan pendekatan $\mathrm{P}$ seperti yang sudah dijelaskan . guru memberikan tes formatif pada pertemuan II setelah kegiatan pembelajaran pada siklus II dari pertemuan I dan II dilaksanakan maka selanjutnya diadakan refleksi dalam bentuk diskusi. Refleksi dan analisis hasil tes (unjuk kerja) pada siklus II terdapat 24 siswa atau 100\% . dari hasil pengamatan tersebut siswa sudah mulai terbiasa dengan pembelajaran karena guru selalu memberikan motivasi belajar. Guru sudah mulai optimal dalam membimbing siswa pada saat duduk berpasangan, adanya ketegasan guru saat menegur siswa yang melakukan kesalahan. Berikut table hasilbelajar Siswa 
Table 4.6 Distribusi Hasil Belajar IPS pada Siklus II

\begin{tabular}{|c|c|c|c|}
\hline $\mathrm{No}$ & Skor & frekuensi & $(\%)$ \\
\hline 1 & 81 & 4 & 16.7 \\
\hline 2 & 84 & 3 & 12.5 \\
\hline 3 & 90 & 2 & 8.3 \\
\hline 4 & 91 & 2 & 8.3 \\
\hline 5 & 92 & 4 & 16.7 \\
\hline 6 & 93 & 3 & 12.5 \\
\hline 7 & 94 & 1 & 4.2 \\
\hline 8 & 95 & 2 & 8.3 \\
\hline 9 & 96 & 1 & 4.2 \\
\hline 10 & 97 & 2 & 8.3 \\
\hline \multicolumn{3}{|c|}{ Jumlah } & 100 \\
\hline
\end{tabular}

\subsection{Hasil Penelitian}

Berdasarkan hasiltindakan yang telah dilakukan dapat diketahui telah terjadi pningkatan hasil belajar IPS melalui model Pembelajaran Kooperatif Picture and Picture pada siswa Kelas V A SD Negeri 200402 Sabungan Padangsidimpuan keberhasilan tersebut dapat dilihat pada table berikut:

Table 4.7 Perbandingan ketuntasan Hasil Belajar IPS pada Pra Siklus, Siklus I dan Siklus II

\begin{tabular}{|l|l|l|l|l|l|l|}
\hline $\begin{array}{l}\text { Ketuntasa } \\
\text { n Belajar }\end{array}$ & \multicolumn{2}{|l|}{ Pra Sikus } & \multicolumn{2}{l|}{ Siklus } & \multicolumn{2}{l|}{ Siklus II } \\
\cline { 2 - 7 } & $\begin{array}{l}\text { Fre } \\
\text { k. }\end{array}$ & $\%$ & $\begin{array}{l}\text { Fr } \\
\text { ek }\end{array}$ & $\%$ & $\begin{array}{l}\text { Fr } \\
\text { ek }\end{array}$ & $\%$ \\
\hline Tuntas & 14 & 58, & 1 & 7 & 2 & 100 \\
& & 3 & 8 & 5 & 4 & \\
\hline $\begin{array}{l}\text { Tidak } \\
\text { tuntas }\end{array}$ & 10 & $\begin{array}{l}41, \\
7\end{array}$ & 6 & 2 & 0 & 0 \\
\hline
\end{tabular}

\section{PEMBAHASAN}

Focus perbaikan pada penelitian ini adalah peningkatan hasil belajar IPS melalui pendekatan Kooperatif Picture and Picture . trianto \{2007:113\} mengemukakan bahwa pendekatan ini merupakan cara berfikir tentang apa yang baru dipelajari atau berfikir kebelakang tentang apaapa yang sudah kita lakukan dimasa yang lalu dan merupakan respon terhadap kejadian serta aktivitas ataupengetahuan baru yang diterima atau dilakukan. Kelebihan strategi ini adalah dapat melibatkan seluruh Berdasarkan hasil penelitian, kegiatan pembelajaran di Kelas V A SD Negeri 200402 Sabungan Padangsidimpuan terlihat bahwa ada peningkatan hasil belajar IPS melalui pendekatan Kooperatif Picture and Picture sebelum diadakan tindakan skor rata-rata 72,30 skor tertinggi 80 skor terendah 50 dan setelah diadakan tindakan penelitian pada siklus I skor rata-rata menjadi 85,27 dengan skor tertinggi 94 dan skor terendah 64. Hasil siklus I dengan tingkat keberhasilan $75 \%$ dari jumlah siswa 18 orang menunjukkan pada siklus I ini hasil belajar IPS sudah meningkat, masih ada siswa yang belum tuntas dengan persentase $25 \%$. Persentase ini sudah memenuhi target indicator keberhasilan siklus I yaitu lebih besar dari 75 namun belum memenuhi ketuntasan ahir penelitian yang ingin dicapai $100 \%$ dari seluruh siswa sehingga perlu dilakuakan tindakan siklus II . perolehan hasil belajar pada soklus I ini masih belum optimal, beberapa kekurangan dalam penelitian tindakan siklus I ini antara lain dalam menyampaikan tujuan pembelajaran guruterlalu cepat, sehingga siswa kurang mengerti apa yang harus dia pahami ketika pembelajaran. Pembagian kelompok yang belum disiapkan sebelumnya , dalam menajemen waktu pembelajaran perlu ditingkatkan sehingga pembelajaran berlanngsung lebih efektif dan efisien. Guru kurang membimbing siswa melaksakan langkah pembelajaran, selain itu pemberian kesimpulan pada ahir pelajaran perlu dilakuakan bersama-sama siswa. Semua siswa harus beraktivitas positif dalam pembelajaran sehngga siswa memperoleh manfaat pembelajaran melalui pendekatan Kooperatif Picture and Picture

\section{SIMPULAN}

Berdasarkan hasil Penelitian Tindakan Kelas (PTK) yang dilaksanakan dalam dua siklus tersebut, maka dapat disimpulan bahwa dengan menggunakan model pembelajaran Picture and picture dapat meningkatkan hasil belajar IPS siswa kelas V A SD Negeri 200402 Sabungan Padangsidimpuan tahun pelajaran 2017-2018. Hal ini ditunjukkan dengan adanya peningkatan jumlah siswa yang mencapai nilai ketuntasan belajar dengan $\mathrm{KKM} \geq 75$ adalah sebanyak 14 siswa $(58,3 \%)$ sedangkan siswa yang tidak mencapai ketuntasan belajar sebanyak 10 siswa $(41,7 \%)$ pada pra siklus (kondisi awal) sebelum dilaksanakan tindakan.

Setelah memperoleh tindakan pembelajaran dengan menggunakan model pembelajaran Picture and picture ketuntasan 
belajar dengan KKM $\geq 75$ meningkat menjadi 18 Mudjiono, Dimyati. 2009. Hasil Belajar siswa $(75 \%)$ yang tuntas dan 6 siswa $(25 \%)$ tidak tuntas pada siklus 1 ; dan 24 siswa $(100 \%)$ yang tuntas pada siklus 2. Nilai rata-rata siswa tiap Sulistya, Naniek. 2012. Upaya Meningkatkan siklusnya juga mengalami peningkatan, yaitu pada pra siklus (kondisi awal) sebelum dilaksanakan tindakan sebesar 72,30 menjadi 85,27 pada siklus 1 , sedangkan pada siklus 2 meningkat menjadi 90,10. Dari hasil penelitian yang telah dilaksanakan maka hipotesis dalam penelitian ini terbukti dapat meningkatkan hasil belajar IPS siswa kelas V A SD Negeri 200402 Sabungan Padangsidimpuan tahun pelajaran 2017-2018.

\section{DAFTAR PUSTAKA}

Arikunto, Suharsimi. 2002. Dasar-dasar Evaluasi Pendidikan. Jakarta: Rineka Cipta.

Badan Standar Nasional Pendidikan (BSNP). 2006. Standar Isi dan Standar Kompetensi

Lulusan Tingkat Sekolah Menengah Pertama dan Madrasah Tsanawiyah (Permen Mendiknas No. 22, No. 23, dan No. 24 Tahun 2006). Jakarta: PT. Binatama Raya.

Ibrahim, M. \& Nur, Mohamad. 2000. Pembelajaran Kooperatif. Surabaya: University Press.

Moentoyah. 1993. "Aspek-aspek Psikologi dalam Kesulitan Belajar pada Anak dan Remaja". Makalah Seminar Kesehatan Jiwa Semarang.

Nurhadi. 2004. Pembelajaran Kontekstual dan Penerapannya dalam KBK. Malang: Universitas Negeri Malang.

Rianto, Yatim. 1996. Metodologi Penelitian Pendidikan Suatu Tinjauan Dasar. Surabaya: SIC Surabaya.

Slameto. 2001. Evaluasi Pendidikan. Jakarta: Bumi Aksara.

Sapriya. 2008. Hakekat Pendidikan IPS. Arifahanwar.com

Hamdani. 2011. Penggunaan Metode Picture and Picture Dengan Media Gambar. Repository.library.uksw.edu

Saprijono, Bloom. 20011. Prinsip - Prinsip Belajar. Eprints.uny.ac.id

Hamalik, Oemar. 2004. Pengertian Belajar dan Hakikat Belajar. educationvionet. blogspot.com

Purwanto. 2008. Pengertian Hasil Belajar Menurut Para Ahli. ebookbrowsee.net Pengertian dan Definisi. indramunawar.blogspot.com

Kreativitas Siswa Dalam Pembelajaran IPS SD Melalui Diskusi Kelompok. repository.library.uksw.edu

Purwanti, Endang. 2008. Beberapa Macam Teknik Non Tes Menurut Endang Purwanti. repository.library.uksw.edu

Mulyas, E, 2007. Dalam Pembelajaran Mata Pelajaran IPS. eprints.uny.ac.id KTSP. 2006. Pembelajaran

IPS. https://hendraprijatna68.files.wordpress.com

Syah, 2006. Penggunaan Metode Picture and Picture Dengan Metode Gambar. repository.library.uksw.edu

Djamarah, Syaiful Bahri, 2002. Penerapan Model Pembelajaran Kooperatif Tipe Picture and Picture. digilib.unpas.ac.id

Uno, B Hamzah. 2011. Menjadi Peneliti PTK Yang Profesional. Yogyakarta: Bumi Aksara

Emzir. 2009. Pendekatan Kuantitatif dan Kualitatif. taliabupomai.blogspot.com

Biklen, Bogdan. 1982. Metodologi Penelitian. repository.upi.edu

Johnson,Johnson. 2011. Model Pembelajaran Picture and Picture. www.ras-eko.com 